Article

\title{
Medical Tourism Markets: Models of Sustainability. The Case of Spain and The Costa del Sol (Malaga)
}

\author{
Ricardo Pagan ${ }^{1, *}$ and Daniel Horsfall ${ }^{2}$ \\ 1 Department of Applied Economics, University of Malaga, 29071 Malaga, Spain \\ 2 Department of Social Policy and Social Work, University of York, York YO10 5DD, UK; \\ daniel.horsfall@york.ac.uk \\ * Correspondence: rpr@uma.es
}

Received: 9 August 2020; Accepted: 19 October 2020; Published: 23 October 2020

check for updates

\begin{abstract}
The interest and relevance of medical tourism has increased significantly over the last few decades, and it has become a very lucrative source of income and profit for many firms. This paper analyses the sustainability of the medical tourism model in Spain in general, and in The Costa del Sol (Spain) in particular, in order to investigate the potential challenges that the domestic industry will face in the future. For this purpose, we first analysed the process of the globalization of health services and the main characteristics of the Spanish medical tourism industry (in terms of tourism and health services). Second, we examined the data availability on medical tourism for the cases of Spain, Andalusia and The Costa del Sol, and identified who travels, why, and for what reasons. The results show that Spain and The Costa del Sol offer high-quality medical and tourism facilities and services with very competitive prices, and with the high commitment and support of public local authorities, tourism and health providers, and universities. However, the lack of a real leadership, well-defined strategy, financial support, and specific training programs are considered to be crucial challenges for the near future. In addition to this, the novel coronavirus, the economic crisis, Brexit and the situation of British expats living in Spain and The Costa del sol are also discussed.
\end{abstract}

Keywords: medical tourism; sustainability model; data availability; coronavirus crisis; Brexit; British expats; Spain; the Costa del Sol

\section{Introduction}

Medical tourism is no longer a 'new' phenomenon, with the industry burgeoning throughout the first twenty years of this century. The range of services being offered, the destinations offering them, and volume of medical travelers has increased substantially, which points-at least superficially-to a market that is here to stay. This undoubtedly speaks to one facet of sustainability; however, this sustainability is uneven. Any review of medical tourism providers over the past twenty years would show tremendous churning; indeed, even the very destination countries have changed substantially, with some of the most popular locations—such as Poland-having been relatively unknown in the medical tourism market at the turn of the century [1].

The reality is that medical tourism is not one single industry with providers competing in the same market, governed by the same rules. As such, even if industry projections and figures speak to broad sustainability, this varies by the destinations' type as a consequence of country-specific issues. While many individual providers may enter the market in the hope of appealing to the 'customer in search of value', traditional marketing concepts related to the cost of the product, word-of-mouth recommendations, advertising campaigns, and price differentials—while important-may be less important than wider trends. These include historic trade-patterns, geo-political issues, and cultural ties [2]. For example, Poland—as previously mentioned, a relatively new player in medical tourism-is 
a major destination for medical travelers from the United Kingdom (UK). However, many of these are Polish citizens; these patterns reflect wider migration patterns [3], and are undoubtedly likely to be changed somewhat by the UK's withdrawal from the European Union (EU). Spain, on the other hand, is similarly a popular medical tourism destination for British residents, but unlike the Polish case, most of these medical tourists from Britain are British citizens, rather than Spanish citizens. While price differentials play an important role in attracting any medical tourist to any destination, the linkage between the UK and Spain is very different from that between the UK and Poland. Here, the flow of medical travelers reflects the historic patterns of tourism underpinned by the close historical, economic and political ties between Spain and the UK [4].

The purpose of this paper is not-primarily-to assess the strengths or quality of medical tourism in the Costa del Sol—or Spain more widely—but rather to consider what features of the industry here are likely to support sustainability in the face of key challenges. To this end, the paper begins by outlining the broad basis for the general sustainability of medical tourism, highlighting some of the challenges being faced by the industry, before considering the Spanish case in more detail. Here, we can see that the Spanish model is underpinned by a strong tourism sector, an established and respected health system, some state support for the sector, and deep and historic cultural, political and economic ties with countries that continue to represent key sources of medical tourism. While the immediate future is set to be challenging for all tourism destinations, and in particular medical tourism providers, there is an inherent strength in the Spanish model, which is a source of optimism. This paper provides data on medical tourism flows into Spain and the Costa del Sol region in order to underpin the argument that the local industry is built upon strong foundations, before breaking these down in order to highlight the importance of historical economic and migratory patterns. The concept of sustainability is complicated when it is applied to medical tourism; are we discussing sustainability at the industry level, the country level, the local level, or at a micro level, differentiating between different forms of medical treatment or even individual providers? Whether medical tourism is sustainable depends on the level in which we are interested. Over the first two decades of this century-even looking beyond industry boosterism - the numbers of those travelling for treatment has undoubtedly increased; however, some countries have emerged or disappeared as leaders from the landscape, the churn of individual providers has been immense, and even the forms of treatment being offered and sought have altered. We consider the ways in which Spain in general-and the Costa del Sol region particularly - has fared and is likely to react to future pressures. We find that, while times are indeed challenging, the fact that the Spanish medical tourism sector does not simply rely on 'customers in search of value', but rather taps into wider trade relationships and patterns of migration, is a key source of its sustainability.

\section{The Globalization of Health Services: New Perspectives and Markets}

Medical destinations abroad may become more attractive as price differentials become more pronounced due to supply and demand shifts within nations. The number of countries that are trying to develop medical tourism and attract this new segment in the tourism industry has increased rapidly, and it has become very attractive to elites in developing countries [5]. For example, Thailand, Singapore and India are top medical tourism destinations in Asia, based on the existence of medical specialties, international accreditations, and competitive prices compared to other potential competitors [6,7]. The relative price differentials in different industries creates the movement towards, and cost saving potential for, cross-border arbitrage for a specific product or service. Health insurance pilot programs are adding coverage for care across borders in an effort to reduce their own costs and to reduce costs for their clients, both public and private [8]. The element of cost includes more than treatment, as it also combines other factors such as travel and accommodation. Other elements can be taken into account, such as, for example, the improvements in health standards (e.g., Joint Commission International Accreditation) and available technology that allow the integration, coordination, monitoring and traceability of the full health-care process (i.e., pre-, during- and 
post-health care). The improvement of the quality requires the existence of multidisciplinary-trained healthcare teams, clinical information technologies, evidence-based clinical guidelines, and the participation of academic institutions [9].

Technological change has made it easier for consumers to find and access services from all over the globe, and to share their experiences with others. The increased use of the internet by consumers has made it easier to conduct research to seek out care from the available providers in other locations, and to coordinate travel and accommodations. Technology has also changed the impact of healthcare on patients. Patients are more likely to consider traveling for care, and are more likely to engage in leisure activities during their stay. In addition, technology has allowed for the early detection of diseases and conditions, which further fuels demand for treatments [10].

Medical tourism can reduce the boom/bust nature of economies which are dependent on a few isolated industries. This includes locations that rely on tourism and other industries that are either cyclical or seasonal in nature, because the market for healthcare may minimize the exposure to cyclical downturns or off-peak slow seasons, ultimately leading to a reduction of seasonality and cyclicality. Medical tourism can also draw tourists to a destination that they may otherwise not have visited, strengthening the destination's brand and broadening the target consumer demographic for tourism to that area, thus diversifying the tourist base. This fact may reduce the cost of destination marketing. The development of medical tourism can attract educated and skilled labour to the destination, and keeps graduating students from leaving to seek employment elsewhere.

According to Wendt [11], "the medical tourism market can also improve the quality of local education through collaboration between local medical facilities and universities" (p. 27). Attracting world renowned medical centres of excellence to a destination can create a cluster and partnership effect, attracting other high-revenue support industries to serve existing medical facilities, and attracting venture capital and entrepreneurship activity [11]. In addition, collaboration and strategic partnerships have shaped the growth of health tourism internationally, allowing companies to capture a share of the market for health travel in other countries [11]. Local, state, and national governments; destination marketers; medical institutions; trade associations; health insurance providers; medical travel agencies; hotels; and other industry players have joined efforts to coordinate health and tourism activities. The main effect of this cooperation is the creation of synergies and scale economies due to the reduction in costs. However, Connell [12] points out that "medical tourism has transformed the geography of international health care, but much of what has been written of this transformation has been speculative, optimistic and distanced from detailed documentation and analysis of medical tourists mobility" (p. 10). According to Hanefeld and Smith [13], it is necessary to have "better and clearer data on all forms of trade in health-related services in order to understand impact and to minimize risks and maximize the potential of such trade in the future" (p. 42). Within this scenario, the roles of private healthcare providers, medical travel facilitators, policy makers, and national governments are essential instruments to promote medical tourism destinations as a source of foreign revenue $[14,15]$.

\section{Data on Spain}

Spain has become one of the most relevant and strong countries in the world in terms of tourism and health services. From a tourism perspective, Spain ranks second on the World Tourism Organization's list of the most visited countries in the world, and is considered as a consolidated, mature and competitive destination [16]. According to the latest figures, the tourism industry accounts for $16 \%$ of its gross domestic product (GDP), employs $13 \%$ of its total employment (around 2.5 million), a total amount of revenue generated of almost 92.2 billion euros (a $2.82 \%$ rise compared to 2018), and 83.7 million tourists (a 1.08\% increase compared to the statistics from 2018) in 2019 [17]. British tourists still represent the highest proportion of tourists visiting Spain (18.08 million), followed by Germans (11.18 million) and French tourists (11.16 million). By region, Catalonia is the region that 
attracts the highest number of travellers (19.36 million), followed by the Illes Balears (13.68 million), the Canary Islands (13.15 million) and Andalusia (12.08 million).

As for the Spanish medical system, and according to IDIS (Instituto para el Desarrollo e Integración de la Sanidad) [18], healthcare spending represented 9\% of the total GDP in 2016, slightly above the Organisation for Economic Co-operation and Development's (OECD) average (8.9\%), but behind neighbouring countries such as France (11.5\%), Germany (11.1\%) and the United Kingdom (9.85\%). According to the World Health Organization [19], health systems in Mediterranean countries-such as Spain, France and Italy-are located in the top of the ranking compared to others in Europe. Spain is ranked as the 7th best healthcare system in the world, thanks to more than 800 hospitals (public +private), and around 480,000 doctors and nurses.

Within this context, Spain offers a plethora of high-quality medical facilities and equipment at lower costs in comparison with those found in, for example, the United States, and attracts many medical tourists from the United Kingdom, the Middle East, and Northern Africa (health-tourism.com). Long waiting lists, higher health care costs, geographical proximity, technological advances, and the unavailability of services in these countries of origin are traditionally mentioned as the main reasons for this increase in medical tourism to Spain [9]. Spain has globally recognized doctors and scientists, and reputed clinics and hospitals specializing in traumatology, cancer treatments, ophthalmology, and cardiology, and is a leader in terms of the demand for medical services related to cosmetic surgery, assisted reproduction and artificial insemination (health-tourism.com). According to IDIS [20], medical tourism reached a total economic volume of 321.9 million euros in 2014, a $25 \%$ increase on the previous year. In addition, Spain ranks sixth in Europe and eighth worldwide as a medical tourism destination. In terms of the source of these medical tourists, $63 \%$ of Spain's foreign patients are from Germany, 19\% are from France, 5\% are from the UK, 5\% are from Italy, 4\% are from Austria, 3\% are from Sweden, and 1\% are from other countries [20]. As for prices, for example, cosmetic surgeries cost $60 \%$ more in the UK compared to those found in Spain, and the cost of a knee or hip replacement represents around $50 \%$ of that found in the UK.

\section{Data on Andalusia and Malaga (The Costa del Sol): Motivations for Travel}

Andalusia is located in the south of Spain, covering $87,268 \mathrm{~km}^{2}$, and represents $17.3 \%$ of Spain (the second largest Autonomous Region). Andalusia has almost $900 \mathrm{~km}$ of coastline, and is the home of a large number of important cities, such as Malaga, Cadiz and Almeria. It has become a main holiday destination for international and national tourists thanks to its climate, modern infrastructures and communications, important cultural heritage, and impressive monuments, fiestas, gastronomy, and warm people. According to INE (Instituto Nacional de Estadística) [17,21], in 2019, Andalusia received 12.08 million international tourists ( $3.4 \%$ up on 2018), a total expenditure of 672.4 million euros (6.2\% up on 2018), and an average trip duration of 8.39 days (6.5\% down on 2018).

In recent years, Andalusia has also been marketed as a perfect place to combine health, wellness and pleasure, thanks to the existence of therapeutic treatments at specially designed spas and hotels, and based on thermal waters, mud treatments, massages, therapeutic baths, water jets, and algae therapies, among others. According to the Department of Tourism and Sport of the Andalusian Regional Government [22], Andalusia has 457 establishments offering health and wellness services (33\% and 17.3\% located in Malaga and Granada, respectively) such as spas, baths, saunas, Jacuzzis, pools, and massages, etc. The total demand of health and wellness services was around 860 thousand tourists (of which 21.4\% were international tourists) in 2016 (9.8\% up on 2015). The average duration of the trips was 6.1 days (2.5\% down on 2015), and the average daily expenditure was 68.79 euros $(4.7 \%$ down on 2015).

The province of Malaga (Costa del Sol) has been configured as an open, commercial and hospitable territory, with a wide range of accommodations, leisure activities and healthy gastronomy, turning tourism in general-and medical tourism in particular-into an engine of the utmost importance and relevance for its economy. Overall, in 2018, the number of tourists who visited the 
province of Malaga was 12,556,000 (1.5\% up on 2017), who left an estimated income of 14,200 million euros (2.5\% up on 2017), and there were 173,000 people working in the tourism industry $(4.2 \%$ up on 2017) (visitacostadelsol.com). As for the arrival of international tourists, the most robust market during 2018 was the one coming from the UK, with $9.15 \%$ of the total hotel travellers $(125,286$ in absolute terms); followed by Germany, with 5.22\% (71,502 tourists); France, with $4.81 \%$ (65,804 tourists); Italy, with 4.07\% (55,732 tourists); and The Netherlands, with 3.63\% (49,650 hotel tourists). There has been a spectacular increase in the regulated supply of accommodation in 2018, especially due to increase and registration of 'housing for tourism purposes' (which accounts for $40.9 \%$ of the total supply), followed by hotels $(27.1 \%)$ and apartments $(17.6 \%)$.

The province of Malaga, in addition to being a tourist destination, has developed-in recent years-an ambitious and important strategic plan to become a top medical tourism destination [23]. Firstly, we have to bear in mind that Malaga has been configured as a strategic point within the national geography at the technological, university and business levels. Malaga has excellent communications (e.g., a new international airport with multiple international destinations, and high-speed rail connections with the capital, Madrid), one of the technology parks in the most relevant development in the country, a prestigious public university, and excellent high value-added basic services [23]. The immediate consequence of all of this is an activity which is not only economic, but also includes business and high added-value services, linked by the combination defined through the formula: knowledge + innovation + welfare.

Secondly, one of the most key points and attractive characteristics about Malaga is that there are around 30 private clinics and hospitals (e.g., Hospital Vithas Xanit Internacional in Benalmádena (with the Joint Commission International (JCI) Certification), and Clínica Buchinger Wilhelmi and Hospital Quirón in Marbella), which concentrate around $45 \%$ of the total beds in private hospitals in Andalusia [23]. These private hospitals have the best medical equipment, the most professional nurses, and all of the comforts of a luxury hotel in the best tourist environment. Thirdly, Malaga had almost $42 \%$ of Andalusia's four and five star hotels in 2018, and concentrated around $58.5 \%$ of the total regulated supply of accommodations and 33\% of establishments offering spa and wellness services in in Andalusia. Fourth, there are different public and private initiatives aimed at the promotion of the region as a one the best destinations in Southern Europe for medical tourism. For example, in 2013, a cluster focused on health-care tourism (called 'Tourism \& Health Spain, Costa del Sol', with more than 20 companies from both the private and public sectors, and a total of 6500 professionals) was launched in order to provide health treatment packages at competitive prices, which allowed international patients to be treated and operated upon in private hospitals and clinics in Malaga, as well as the opportunity to improve off-season bookings.

In the same vein, the 'Tourist Board of the Costa del Sol', in collaboration with private and public entities, has been also involved in the promotion of healthcare and medical tourism activities in recent years. The Malaga Health Foundation was also created in 2013, in order to promote medical tourism in the city of Malaga. In addition, the University of Malaga created, in 2013, the first Chair of 'Tourism, Health and Wellbeing', dedicated to the design and provision of specific training on health tourism to professionals working in the tourism and healthcare industry, and to carrying out a new field of research on medical and health tourism at the national, regional and provincial levels.

Overall, the province of Malaga has created an excellent ecosystem of health-medical tourism formed by private health care providers (e.g., hospitals and clinics), the hospitality sector (e.g., hotels, spas, wellness and beauty centres, and restaurants, etc.), facilitators/brokers (e.g., travel agencies, insurance companies, and national clusters (for example, Spaincares), public institutions (e.g., national, regional and local authorities, universities, and technological parks), and health/medical tourists (e.g., international tourists coming from the UK, Germany, France, and the United Arab Emirates). This has not occurred by chance; rather, a concerted and coordinated approach by healthcare providers and the local government has facilitated such growth. The success of this industry is intrinsically 
linked with the success of the region, which has supported the medical tourism sector in the hope of reaping the wider economic benefits.

From a methodological point of view, one of the main limitations of the investigation of health/medical tourism is the lack of reliable and comparable international data on the specific procedures that these patients seek, how many patients are involved, and how much expenditure occurs [24]. In Spain in general, and in Malaga in particular, it is quite difficult to find rigorous data on health/medical tourism from official public sources that use an internationally standardised definition, appropriate methodology and comparable indicators. In our case, we have adopted an approach based on quantitative and qualitative data (from public and private sources) which is similar to other existing studies on medical tourism $[7,25]$. In particular, we used information provided by the Spanish National Statistical Institute (INE, quantitative data), and the Chair of 'Tourism, Health and Wellbeing' of the University of Malaga (quantitative and qualitative data) in order to obtain the most clear and precise picture on the present and future of medical tourism in the province of Malaga. These two sources were the only ones to include these kinds of data at a local level. In any case, and according to Connell [26], we have to bear in mind that the key point about the lack of appropriate data on the magnitude of medical tourism is that they are held in private hands, and in organizations with important commercial interest in this sector. Horsfall and Lunt [27] conclude that "estimating the global flows of medical tourists is not simply difficult, it only reveals part of the story" (p. 33).

Horsfall and Pagan [3] point out that Spain has become the main European destination for people born in the UK who choose to migrate to EU countries, and Andalusia-especially the province of Malaga - is one of the most popular regions preferred by them. Using data taken from the Municipal Register (INE) (the Municipal Register is an administrative register where inhabitants are recorded and updated annually), Figure 1 shows the total number of UK expats living in Malaga during the period 2003-2017. For comparison reasons, it also includes the total number of expats living in Germany, Morocco, China, The Netherlands and Finland. We have also replicated Figure 1 using data for Spain and Andalusia. Overall, the results are quite similar to those shown in Figure 1, except for the case of Morocco in 2017, where a strong fall is found in both Spain and Andalusia with respect to 2012 (10\% and $60 \%$, respectively) (these results are available upon request).

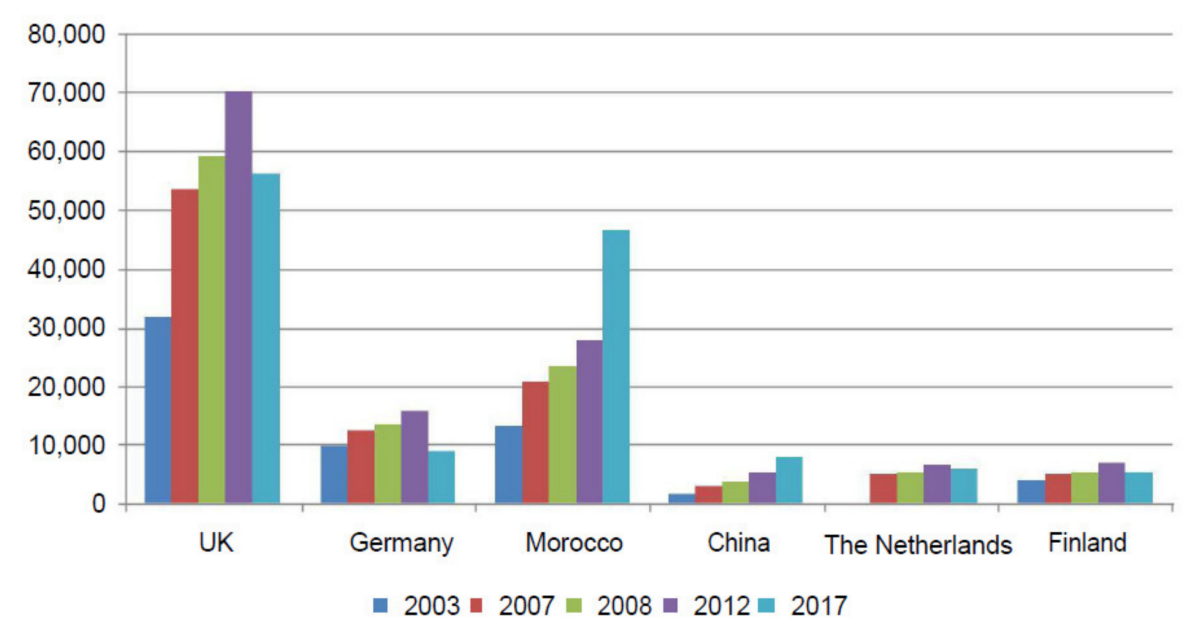

Figure 1. Residents in Malaga coming from the UK, Germany, Morocco, China, The Netherlands and Finland during the period 2003-2017. Source: the Municipal Register (period 2003-2017), Spanish National Statistical Institute.

According to Figure 1, and in line with Horsfall and Pagan [3], the total number of UK expats in Malaga increased between 2003 and 2012 (from 31,000 to 70,000), but from 2012, the trend has been negative, and with a significant fall (around 13,500 fewer UK expats). As Horsfall and Pagan [3] mentioned, in 2012, there was a Royal Decree Law (RDL) of April entitled 'Urgent measures to guarantee the sustainability of the National Health System and improve the quality and safety of services' [28], 
which introduced severe restrictions to access to the Spanish Public Healthcare System. These measures included stripping foreigners who are neither registered nor authorized as residents in the country of the right to health care. According to Figure 1, we find the same pattern for German expats, with a fall in 2017 of around 40\% with respect to 2012 (more than 9000 individuals). Conversely, the number of expats from Morocco increased during the whole period, especially in 2017, in which the rise was around $170 \%$. Morocco's proximity to Malaga and the regular good communications (by sea and air) between Malaga and Morocco have surely contributed to the increase in this period. There has also been an increase in the number of residents coming from China (mainly richer people) who have found, in Malaga, an excellent place to live and enjoy their retirement by buying a house (according to the current Spanish legislation, anyone can achieve automatic residency by purchasing property valued at 500,000 $€$ or more) or running a new business related to real estate, and the maintenance and construction of luxury town houses, apartments, and commercial properties (e.g., in Marbella or Estepona). Finally, we have also found a positive trend in the number of expats coming from Finland and The Netherlands.

The existence of these expats from different countries in the province of Malaga has contributed to the creation of strong and, in many cases, solid and permanent bonds (e.g., with British expats for more than 40 years), which have permitted the flow of many of their compatriots looking for medical or health treatment to Malaga. Although there is no official data regarding the total number of these international tourists seeking medical or health treatment in the province of Malaga, there have been some previous studies and reports based on health care suppliers' opinions and internal data that may help us shed further light on this phenomenon. Padilla and Del Águila [29] analysed the segment of health tourism in the Costa del Sol in 2010, collecting information from the different websites (42 in total), telephone questionnaires to managing directors (69 valid answers), and personal interviews (10 in total). They found that most of the international health tourists came from the UK and Germany, and the most commonly offered services for medical wellness and wellness (thalassotherapy/spa) were topical treatments (e.g., bath pressure, massage therapy, baths without pressure, stoves, and physiotherapy), and beauty and anti-aging (e.g., skincare, body treatments, body aesthetics, and aesthetic plastic surgery), whereas for private health clinics, they were ophthalmology, oral and maxillofacial surgery, and orthopaedic surgery and traumatology. They concluded that even though the health tourism sector has developed in recent years in Malaga, there is still work to do to integrate, rationalise, and provide quality services around this activity, alongside the need to be considered as a different tourism product, which still has a low level of penetration within the distribution channels, a high level of fragmentation of its sector, and for which it is important to design and implement more cooperation actions between the existing companies.

As noted earlier, in 2013, the University of Malaga created the Chair of 'Tourism, Health and Wellbeing', and started to investigate the health tourism sector in Spain and Malaga from a demand and supply perspective. For this purpose, they carried out different types of qualitative and quantitative studies for the province of Malaga in order to identify the main markets of health tourists, their reasons for travelling to Malaga, the most popular products and services, the best distribution channels, the potential for cooperation between sectors and companies, the level of participation and compromise of local public authorities, and strategies and actions for the achievement of the sustainability of health tourism industry in the long run. Table 1 shows the top 10 medical treatments demanded by international tourists in private hospital and clinics, and their countries of residence in Malaga in 2016. 
Table 1. Ranking of the most demanded medical treatments in Malaga, and the main countries of residence of the patients (2016).

\begin{tabular}{ccc}
\hline Ranking & Speciality & Countries \\
\hline 1 & Traumatology and orthopaedic surgery & UK, Germany and The Netherlands \\
2 & Ophthalmology & UK, Portugal and The Netherlands \\
3 & Cosmetic surgery & UK, Russia, Arabic countries, and France. \\
4 & Obesity treatments & UK and USA \\
5 & Cardiology & Russia, USA, Scandinavian countries and Arabic countries \\
6 & Neurosurgery & Russia, USA, and Arabic countries \\
7 & Infertility treatments & Italy, UK, France, Portugal and The Netherlands \\
8 & Oncology & Russia, and Scandinavian countries \\
9 & Rehabilitation treatments & Germany and The Netherlands \\
10 & Odontology and maxillofacial treatments & UK, Portugal and The Netherlands \\
\hline
\end{tabular}

Source: the Chair of 'Tourism, Health and Wellbeing' (2016).

In line with other previous studies for Spain [30], traumatology and orthopaedic surgery are the top medical procedures in the province Malaga, with international tourists coming from the UK, Germany and The Netherlands. Ophthalmology and cosmetic surgery occupy the second and third position. Obesity treatments are located in fourth place, with patients coming mainly from the UK and the USA. It is worthwhile to mention that the UK market is one of the main sources of tourists within the top four medical treatments abroad. More complex surgeries, such as cardiology, neurosurgery and oncology, are well-located in the ranking (with a significant presence of Russians and Arabs), as well as the infertility treatments (e.g., artificial insemination or in vitro fertilisation) thanks to the lenient Spanish legislation compared to other neighbouring countries, such as France and Italy (two of the main countries looking for these treatments in Malaga). Finally, rehabilitation, odontology and maxillofacial treatments are also highly demanded by international tourists, mainly those coming from the UK, Portugal, Germany and The Netherlands.

Apart from the conditions of the province of Malaga, which were mentioned earlier (e.g., climate, accessibility, infrastructure, technology, accreditations of quality, culture, gastronomy, leisure activities, accommodation, prices, a friendly environment, and legislation, etc.), many British expats come to Malaga in order to avoid long waiting lists in their National Health Service (NHS), and to obtain good service quality, geographical proximity, and completive prices [4]. In contrast, Russians and Arabs visit Malaga mainly due to the lack of availability of health-care services and technological advances in their countries of origin. In other cases, the existence of agreements between some European countries (e.g., Scandinavian countries) and some local authorities (e.g., with the town of Benalmadena) has promoted the constant and regular flow of international patients (mainly the elderly, seeking rehabilitation services after traumatology surgery) to the province of in the last few years [4].

\section{Discussion: Opportunities and Challenges in the Future}

The growth in medical treatments for international tourists in the province of Malaga has been significant in recent years, and has allowed the region to reduce the effects of the extreme seasonality of the tourism industry on the levels of income, employment, and welfare. In this sense, to have success, it is necessary to make many inputs available: well-qualified medical professionals, adequate accommodation, an excellent transport network and international connectivity, a good supply of leisure activities that complement the medical supply, international facilitators, insurance providers, and legal security, among others. Medical tourism represents a significant opportunity to attract large numbers of consumers looking for medical care and leisure. Affordability and the opportunity to vacation are amongst the main reasons for the growth in medical tourism [31-33]. In addition, medical tourism provides privacy and anonymity [34]. The ageing population is an excellent opportunity to increase medical tourism (e.g., 'Geriatric Tourism' as a new and separate segment from medical or wellness tourism)' owing to the fact that older people require more expensive surgeries, sophisticated medical 
technology, and intensive rehabilitation services. In addition, the presence of an older expatriate population in certain regions will increase even more the possibilities of the development of medical tourism [4].

The new EU directive on cross-border health care could also be a good booster to increase medical tourism activity (see Directive 2011/24/EU). This directive allows EU citizens to obtain health care and medical services in another EU Member State, establishing standard operating procedures and a system of reimbursements with their own country. Furthermore, the EU directive guarantees the right to a copy of your medical records and, if you need follow-up assistance, you are entitled to receive the same follow-up care that would have been provided in your home country. According to Androutsou and Metaxas [35], there has not been a considerable efficiency improvement after the implementation of the EU directive, because the Directive was not properly disseminated to European citizens. However, these authors point out that cross border health/medical tourism is gaining great interest, and an early-stage collection of reliable data has been performed by member states. The openness of new markets in countries such as the United Arab Emirates (UAE) has contributed to an increase in the total number of medical tourists travelling to Europe (e.g., to Spain, thanks to its cultural and historical roots, and its affinity with the UAE) instead of the USA and UK. However, recently, the UAE has increased its medical reputation with a huge public investment in world-class medical facilities, with high treatment standards for international patients. The difficult political and socioeconomic situation in traditional tourism destinations such as Tunisia, Turkey and Egypt has also contributed to the increase in the flows of medical tourists towards other regions, such as Spain, Hungary, Croatia and Poland.

From a stakeholder perspective, some previous studies have recognized the need to bridge the gap between hotels and healthcare providers [36-40]. For example, Hudson and Li [39] developed an integrated model of medical tourism that includes an element called 'Hotels to Healthcare' $(\mathrm{H} 2 \mathrm{H})$; an overlap between hotels and resorts and the medical facilities (hospital and clinics) themselves, providing an integrated medical tourism facility. This $\mathrm{H} 2 \mathrm{H}$ model is based on the idea of building rooms that feel more like a hotel room than a hospital room (more 'hotelised' hospitals), and hotels and resorts with more health care/medical facilities that guarantee the security within its installations (more 'medicalised' hotels). Moreover, Hudson and Li [39] assert that "since quality is of critical importance in a patient's choice of medical tourism destination, a priority for medical institutions in these countries is seeking accreditation to boost patient confidence to better compete in the medical tourism market" (p. 240). This integration and partnership between the tourism and health care industries offers advantages to both sides by taking advantage of operational synergies, generating economies of scale, increasing productivity and innovation, and being more productive [41]. Furthermore, the availability of these 'medicalised hotels' allows private hospitals and clinics to move patients from its medical rooms to their hotels sooner, facilitating the entry of new international patients into the hospitals. This movement of patients increases the rate of occupancy in both hotels and hospitals, reducing its exposure to demand fluctuation. As noted earlier, in order to facilitate the development and success of this cooperation/integration, an active participation of the government is needed. According to Alberti et al. [42], the government must "act as a facilitator, developing policies to favour medical tourism attraction, meta-managing the destination in health terms and developing paths for industry players integration, providing them sufficient tools, resources and guidance" (pp. 292). In many cases, the role of the government has been vital and crucial to the development and expansion of the medical tourism industry, such as, for example, in Turkey and Thailand [43].

The rise of medical tourism in Malaga has been particularly strong after the financial crisis of 2007, as a new source of earnings, benefits and business opportunities for those elements that support medical tourism. The strategy was mainly based on a horizontal integration of all of these players/co-operators thanks to the creation of new clusters (e.g., Tourism \& Health Spain, Costa del Sol) as a means to offer an integrated package of products and services (wherein potential buyers find an indistinguishable medical/health product and service as a whole), to expand their capacities and define mutual marketing strategies (e.g., the use of the internet, word of mouth, facilitators, 'prescriptors', 
and alliances with governments or insurance companies), the internet, share costs and benefits, and-in many cases-a larger market (the globalization of medical services). The support and compromise of the regional and local authorities have been also high and regular over time, and have allowed the promotion of medical/health products and services in international and national tourism fairs, congresses, conferences, and workshops, as well as the realisation of fun and press trips.

On the other hand, the participation of the University of Malaga (the Chair of 'Tourism, Health and Wellbeing') has been essential to: (a) investigate the potential markets and possible channels of promotion and commercialization; (b) provide ad-hoc training and new skills and capabilities to those players implicated in the medical tourism industry; (c) share and disseminate general and specific data on health tourism at the national, regional and local levels (e.g., studies, academic articles, etc.); and (d) design and implement a new technological platform that permits the integration of all processes and services, from the arrival of the international patients to Malaga, to their the departure to their countries of residence (including all of the rehabilitation procedures and checks after the surgery).

Most clusters of medical tourism created in Malaga in recent years have contracted at a high rate in terms of patients, earnings and revenues. The main reason for this failure has been the lack of leadership, strategy, financial support, training, and real commitment and goals. Being a member of a cluster implies a new way of doing things, based on open collaboration, honesty, and behaving responsibly within a competitive market. According to the Center for Health Tourism Strategy [44], many clusters were created by consultants who set up a corporation, talking about what the cluster will 'do', but never implementing the 'how'. After this, they took all the cash out of it that they could and departed to the next copy/paste cluster project. Furthermore, the Center for Health Tourism Strategy [44] points out that overall poor communication (mainly internal), inadequate and obsolete infrastructures (especially in the tourism industry), reticence to new investments and capital (e.g., in training, software, equipment and staff) and no brand value are also common problems and deficiencies shared within unsuccessful clusters at an international level. The ego factor has been also mentioned as a key reason for failure [44]. Many directors and managers do not want to hear what they have to do, or do not want to share confidential information with other partners of the cluster who are competitors in the domestic market. As a result, each member of the cluster tries to gather all of the available information and data collected by the cluster (and paid for all of the players) and the confidential records of the other members. Once they run out of money, they do not look back, and try to develop their own medical tourism niche within their organizations (under the same philosophy, rules, corporate strategies and human resources) [44].

As for the challenges for the province of Malaga, we can differentiate two different types: general (i.e., affecting all of the countries and regions), and specific (i.e., related to their own destination/territory). Firstly, and as noted earlier, one of the biggest drawbacks in the study of the phenomenon of health/medical tourism is the lack of reliable and up-to-date data. Most of the previous literature on medical tourism has been traditionally based on small samples of individuals for a particular country, and the use of data (qualitative in many cases, thanks to the use of interviews) provided by private sources (e.g., agencies, consultants, hospitals and hotels). It is necessary to use rigorous and harmonised statistical data on medical tourism, which allows us to know, for example, the size of the total market in a particular country or destination, whether the medical travel was self-chosen or the patients have used a facilitator, travel motivations, medical conditions, the total number of nights spent, mean expenditure, satisfaction levels, price elasticities, and expected revenues, etc. These data are essential in order to increase the debate on medical tourism, and to see more clearly the risks and benefits of this new sector.

Secondly, there is no doubt that the immediate global challenge for all economic sectors in general—and the tourism industry in particular-is the coronavirus crisis, which has impacted all economic activity across the world. Here, there are three issues of note, two of which present clear obstacles to the medical tourism industry, and one of which offers an opportunity to providers. The first obvious issue is, of course, the restrictions faced by those wishing to travel. During July 
2020, Spain moved from some of the strictest 'lockdown' measures in the world, which achieved a substantial containment of the virus [45], to a more open approach. While the number of deaths remained low, the UK government still decided to impose a quarantine for those returning from mainland Spain, the Balearics, and the Canary Islands, and made mainland Spain subject to an FCO ( Foreign \& Commonwealth Office) guideline against all but essential travel to the area [46]. While these measures seem disproportionate, and will undoubtedly prove only temporary [46], it is clear that tourism in Spain —and indeed globally—will face a series of challenges in the coming years. One industry-cited reason for the rise in medical tourism stems from the increase in cheap and readily available flights; given the challenges being faced by the aviation industry [47-49], coupled with the looming employment crisis [50], it is unclear whether the boast of cheaper treatment abroad will hold. Indeed, a recent survey of medical tourism providers suggested that two thirds are fearful for the future [51].

The second, related issue is that the broad challenges of the coronavirus to the tourism sector are even more acute for the medical tourism sector. Non-essential, elective procedures are unlikely to be a risk worth taking for many individuals, or worth sanctioning for those bodies or governmental departments that regulate what can and cannot happen in the face of the coronavirus crisis. The nature of medical treatment means that there is potentially a higher risk of transmission owing to increased contact time between people [52-54]. Moreover, as many who travel for more complicated procedures have co-morbidities [55], their risk of infection is both higher and has more serious implications. There is then the added complication in which medical tourism procedures are carried out (usually privately) in public medical facilities, which are now incredibly stretched. While this is not the 'norm' in many countries-Spain included-there are those where such situations occur frequently [56,57]. Even where this isn't the case, many private practitioners may also work in the public sector concurrently [58], or-in more extreme examples-private facilities have been co-opted by the state to help with the coronavirus emergency [59]. This, of course, speaks to the issue of sustainability in the broadest sense; can the medical tourism industry survive? Indeed, already we are seeing within the industry an increased focus on telehealth as a possible alternative growth area for providers.

This second issue does, however, highlight one opportunity for the medical tourism sector, especially in countries such as Spain, which count UK residents amongst their biggest group of 'customers'. One of the key emerging dilemmas in the UK relates to the general pause in non-emergency treatment that is being undertaken within the NHS, so much so that some have begun to suggest that there may be a bigger death toll as a consequence of the lack of treatment for non-coronavirus patients than from the virus itself $[60,61]$. While many non-emergency services are beginning to be offered again, waiting times are high, there is a substantial backlog, and elective procedures are simply not being offered [53,54]. For those providers which are able to offer relatively affordable treatment options in facilities that are able to demonstrate best practice with regards to coronavirus prevention, there is likely to be substantial and, over time, mounting demand [62]. Given that many Spanish providers operate from bespoke clinics without accident and emergency settings, they are in a strong position to meet such a demand. Here, also, even with a mandated quarantine return period, we are talking about patients who may indeed require such a period of convalescence on their return anyway [63].

Thirdly, another important challenge is, of course, Brexit. While it is unlikely that long-term tourism patterns are likely to shift too much, the role of longer-term migration is key. Data from the IPS (International Passenger Survey) has underscored the importance of so-called 'ex-pat' medical tourism, with substantial numbers of those travelling to the UK for treatment actually being UK passport holders who reside elsewhere [3]. Similarly, the importance of migrants from the UK to Spain is crucial for many Spanish providers, especially those in Andalusia [4]. This presents two related challenges for those providers in such a region. While there appears to be a genuine desire for the UK and Spain to reach a prompt agreement on the residency rights of 'ex-pats', the wider political turmoil means that this issue is not yet settled (see Barnier [64]). To this end, it is encouraging that Spain has 
adopted a straightforward 'declaratory' system that allows British nationals to register their residency to demonstrate their right to continue to live, work or study in their chosen country. This, coupled with a warm tone and substantial support for those who already reside in Spain, means that there's no sense that the end of the transition period will see a mass exodus of British ex-pats. That said, there remain many issues that will likely shape the final arrangements between the UK and many member states, as well as the EU as a bloc [64]. This shouldn't be understated as an issue though; work has highlighted the important role of wider historical, cultural, political and economic ties in fostering strong and sustainable patterns of medical tourism flows $[2,65]$. A souring of relationships between the UK and the EU, or Spain specifically, has the potential to impact a range of issues, with nothing being settled until agreements are signed and ratified.

The maintenance of this resident population is crucial, as not only do some of these very people utilise the services of those providers that cater for medical tourists, they also attract friends and family members to the region, and play an important wider role in promoting the Spanish health system through crucial word-of-mouth networks [66,67]. In the short to medium term, then, the strong resident 'ex-pat' community offers a source of stability for the providers that cater to medical tourists-and all private patients-and will help insulate many of the well-established providers from too much flux. The longer-term issue, though, relates to the sustainability of these migration patterns, which have, over the past 30 years, seen many Brits settle in areas such as Andalucía. Even if the right to remain is guaranteed, the ending of free movement means that these communities are likely to dwindle over the next decade or so, with older migrants not being 'replaced' by younger migrants. In some areas where the 'ex-pat' population is dominated by 'sunset migrants', we may be witnessing the last generation of 'ex-pats', with younger Brits being unable to retire abroad both as a consequence of the end of free movement and the changing economic circumstances that facilitated such migration between the early 1990s and today [68]. In an area like Andalucía, however, the 'ex-pat' population is actually rather diverse, with many migrants being of prime working age, raising their children in cities such as Malaga. While there are sunset migrants in this region as well, there are many who retire here having lived and worked in the region for long periods of time. Here again, we can imagine the impact that ending free movement is likely to have.

It is unclear, then, how much of the medical tourism trade from the UK is here to stay in Spain, with many intertwined issues being, as yet, unresolved. However, there is much scope for optimism, as the ties between the UK and Spain—and especially regions such as Andalucía—are strong. It is incredibly difficult to envisage a collapse in tourism between the two countries, and even if the longer-term patterns of migration change, this will take place at such a pace that Spanish providers can adapt. Indeed, while Spanish providers are very responsive to British tastes and requirements, a trip around Malaga and its surrounding area will provide plenty of examples of other communities being catered for, with strong Scandinavian and Russian communities being already established.

Ultimately, though, it is clear that a coordinated response is needed even in a location such as the Costa del Sol—an area of such relative strength. Given the specific threats and weakness that the province of Malaga faces in the short and long run, we also follow the works of MADECA (Málaga, Desarrollo y Calidad) [69] and the Chair of Tourism, Health and Wellbeing [70]:

(1) The adaptation and incorporation of basic medical equipment for the monitoring and recovery of tourists/patients in hotels and resorts make essential a strong economic investment in order to adapt the facilities and establishments within the tourism industry.

(2) The necessity for modernization and updating is detected in some hotels and resorts on the Costa del Sol, in order to attract international medical tourists.

(3) It is necessary to cope with the coexistence of this tourist/patient with other types of tourists whose profile is completely different, as is the case of the sun and beach tourism, or golf tourism.

(4) It is essential to keep improving the levels of training and specialization of the human resources working in the tourism and medical industry, in order to offer a product and service characterised by quality, excellence, and professionalism. 
(5) There exists important national and regional competition within health tourism, which makes business profitability more difficult to obtain and maintain in the time.

(6) At the operational level, and within a more business-like environment, we have to keep working on an effective and real horizontal integration of the tourism and health sector, with a high level of support from the local authorities, and the development of new technologies and emerging platforms.

(7) It is vital to collect more information and data from the demand side (potential clients, markets, and pathologies, etc.) in order to obtain a correct and adequate picture of the medical tourism market, especially at a local level. In this sense, the collaboration with the University of Malaga and other academic institutions and research centres must be promoted, as well as the elaboration of empirical studies and reports on this sector.

\section{Conclusions}

The medical tourism sector faces a number of challenges-some of which strike at the very core of the industry - and there will undoubtedly be providers, and perhaps even entire destinations, that do not prove to be sustainable in either the short or long term. Spain is not insulated from these challenges and there is a worrying time ahead, especially in regions such as the Costa del Sol, in which the medical tourism sector represents substantial economic activity. However, what we have demonstrated here is that the region has much in its favour, at least in terms of maintaining medical tourism at that regional level. First, the cultural, political and economic ties with countries such as the UK - a major source of medical tourists to the region-are strong. Second, as the cost and supply of air-travel is reshaped by the coronavirus, well-travelled routes-such as those between the UK and Spain-are likely to remain the most robust. Third, while Brexit has yet to get even near its resolution, all signs point to at least a mutual desire to maintain a close relationship between the UK and Spain, with the retention of rights for those UK born migrants who reside in Spain being a clear, mutual goal. Fourth, Spain — and parts of Andalucía in particular-have other sizeable and burgeoning migrant populations from regions such as Russia and Scandinavia. Fifth, the medical tourism sector is embedded in the fabric of the Spanish economy, with substantial governmental support, although this needs more coordination and investment. There are other countries and destinations that can boast some of this, but few that can boast all of it. Furthermore, especially in terms of specific treatments, such as fertility treatment, Spain has a strong reputation [71,72].

What we cannot know, of course, is just how far-reaching the coronavirus crisis will prove to be. Spain is in a relatively strong position, but there will undoubtedly be contractions. Small providers are likely to struggle; much of the 'off-the-cuff' or unplanned minor treatments undergone by those who are primarily tourists will almost certainly dry up for the next couple of years. For many of the bigger and more well-established clinics in the Costa del Sol region, this will represent only a small hit, with much of their business being built on higher-end treatments, which are often accessed by resident 'ex-pats' through formal insurance schemes. However, if the perfect storm of deep coronavirus scarring and an acrimonious Brexit come to pass, much of what strengthens the Spanish market would suddenly look less secure.

This study used the best available data on medical tourism in the region, but as acknowledged, medical tourism data is patchy at best and unreliable at worst [12,27]. Both the Spanish and UK governments know far too little-with certainty—about the flows of medical tourists, migrants and, importantly, their consumption behaviours in terms of health care. Similarly, the industry itself is, by its nature, opaque; it is in the interests of those with a stake in the industry to paint a picture of a robust and growing market. Future work must unpick the rhetoric and 'boosterism', and seek to establish a reliable and robust measure of activity in this sector. Similarly, as we move beyond speculation to reality, the impacts of Brexit on individuals and regions must be fully understood; what are the plans of those Brits ageing in Spain? Will economic migrants from the UK still put down roots in Spain in a 
post-free-movement era? How long will the Spanish government or local administrations continue to support the medical tourism sector?

In many respects, the importance of tourism broadly, and medical tourism more specifically, is so intertwined with the Spanish economy that its sustainability is a must.

Author Contributions: Conceptualization, data analysis, writing, review, bibliographic search, and editing, R.P.; writing, review, and bibliographic search, D.H. All authors have read and agreed to the published version of the manuscript.

Funding: This research received no external funding.

Conflicts of Interest: The authors declare no conflict of interest.

\section{References}

1. Horsfall, D. Medical tourism from the UK to Poland: How the market masks migration. J. Ethn. Migr. Stud. 2019. [CrossRef]

2. Lunt, N.; Smith, R.; Mannion, R.; Green, S.; Exworthy, M.; Hanefeld, J.; Horsfall, D.; Machin, L.; King, H. Implications for the NHS of inward and outward medical tourism: A policy and economic analysis using literature review and mixed-methods approaches. Health Serv. Deliv. Res. 2014, 2. [CrossRef] [PubMed]

3. Horsfall, D.; Pagan, R. Jumping the queue? How a focus on health tourism as benefit fraud misses much of the medical tourism story. Soc. Policy Rev. 2017, 29, 219-242.

4. Pagan, R.; Horsfall, D. Medical tourism trends in the United Kingdom 2000-2016 Global economic crisis, migration and UK expats under consideration. J. Tour. Anal. Rev. De Análisis Turístico 2019, 27, $20-40$. [CrossRef]

5. Connell, J. Medical tourism: Sea, sun, sand and y surgery. Tour. Manag. 2006, 27, 1093-1100. [CrossRef]

6. Heung, V.; Kucukusta, D.; Song, H. Medical tourism development in Hong Kong: An assessment of the barriers. Tour. Manag. 2011, 32, 995-1005. [CrossRef]

7. Ebrahim, A.; Ganguli, S. Strategic priorities for exploiting Bahrain's medical. J. Place Manag. Dev. 2017, 10, 45-60. [CrossRef]

8. York, D. Medical tourism: The trend toward outsourcing medical procedures to foreign countries. J. Contin. Educ. Health Prof. 2008, 28, 99-102. [CrossRef]

9. DELOITTE. Medical Tourism; Update and Implications; Deloitte Centre of Health Solutions: Dar es Salaam, Tanzania, 2009.

10. Stephano, R.; Samuels, B. Domestic medical tourism: Establishing U.S. Centers of medical excellence. Medical Tourism Magazine 2012, 23.

11. Wendt, K. Medical Tourism: Trends and Opportunities. Master's Thesis, University of Nevada, Reno, NV, USA, 2012.

12. Connell, J. Contemporary medical tourism: Conceptualisation, culture and commodification. Tour. Manag. 2013, 34, 1-13. [CrossRef]

13. Hanefeld, J.; Lunt, N.; Smith, R.; Horsfall, D. Why do medical tourists travel to where they do? The role of networks in determining medical travel. Soc. Sci. Med. 2015, 124, 356-363. [CrossRef] [PubMed]

14. Neil, L.; Horsfall, D.; Hanefeld, J. The shaping of contemporary medical tourism and patient mobility. In Handbook on Medical Tourism and Patient Mobility; SAGE Publishing, Location: New York, NY, USA, 2015; pp. 3-15.

15. Ghosh, T.; Mandal, S. Medical tourism experience: Conceptualization, scale development, and validation. J. Travel Res. 2019, 58, 1288-1301. [CrossRef]

16. World Tourism Organization. International Tourism Highlights. 2019. Available online: https://www.eunwto.org/doi/pdf/10.18111/9789284421152 (accessed on 27 March 2020).

17. INE. Tourism Movement on Borders 2019. Available online: https://www.ine.es/dynt3/inebase/en/index.htm? padre $=2096 \&$ capsel $=2559$ (accessed on 27 March 2020).

18. IDIS. Private Healthcare, Adding Value Situation Analysis 2019; Instituto Para el Desarrollo e Integracion de la Sanidad: Madrid, Spain, 2019; Available online: https://www.fundacionidis.com/informes/analisis-desituacion-de-la-sanidad-privada/sanidad-privada-aportando-valor-analisis-de-situacion-2019 (accessed on 27 March 2020). 
19. World Health Organization. Measuring Overall Health System Performance for 191 Countries; GPE Discussion Paper Series; World Health Organization: Geneva, Switzerland, 2020; Available online: https://www.who. int/healthinfo/paper30.pdf?ua=1 (accessed on 27 March 2020).

20. IDIS. In Private Healthcare, Adding Value. Situation Analysis 2018; Instituto para el Desarrollo e Integración de la Sanidad: Madrid, Spain, 2018; Available online: https://www.fundacionidis.com/informes/analisisde-situacion-de-la-sanidad-privada/private-healthcare-adding-value-situation-analysis-2018 (accessed on 27 March 2020).

21. INE. Touristic Expenditure 2019. Available online: https://www.ine.es/dynt3/inebase/index.htm?padre= 2483\&capsel=2483 (accessed on 27 March 2020).

22. Department of Tourism and Sport of the Andalusian Regional Government. Turismo de Salud y Bienestar en Andalucía Año 2016. Demanda Turística en Andalucía. Segmentos Turísticos. Available online: http://www.juntadeandalucia.es/turismoydeporte/opencms/areas/servicios/centrodocumentacion/publicaciones/turismo/Turismo-de-salud-y-bienestar-en-Andalucia-00001/ (accessed on 27 March 2020).

23. Aranda, G.; Pagan, R.; Espin, A.; Fernandez, C.; Gutierrez, A.; Prado, M.; Muñoz, J.; Cidoncha, P.; Fernandez, J.; Burgos, J. Proyecto Turismo y Salud: Nuevos Enfoques y Tendencias 2010; Consejería de Turismo, Comercio y Deporte: Sevilla, Spain, 2010; pp. 1-153. ISBN 978-84-694-2414-8.

24. Ruggeri, K.; Záliš, L.; Meurice, C.; Hilton, I.; Ly, T.; Zupane, Z.; Hinrichsf, S. Evidence on global medical travel. Bull. World Health Organ. 2015, 93, 785-789. [CrossRef]

25. Taheri, B.; Chalmers, D.; Wilson, J.; Arshed, N. Would you really recommend it? Antecedents of word-of-mouth in medical tourism. Tour. Manag. 2021, 83, 104209. [CrossRef]

26. Connell, J. Reducing the scale? From global images to border crossings in medical tourism. Glob. Netw. 2016, 16, 531-550. [CrossRef]

27. Horsfall, D.; Lunt, N. Medical tourism by numbers. In Handbook on Medical Tourism and Patient Mobility; Lunt, N., Horsfall, D., Hanefeld, J., Eds.; Edward Elgar Publishing: Cheltenham, UK, 2015; pp. 25-36.

28. BOE. Boletín Oficial del Estado (Núm. 98)—Martes 24 de abril de 2012; BOE: Madrid, Spain, 2012; Available online: https://www.boe.es/boe/dias/2012/04/24/pdfs/BOE-A-2012-5403.pdf (accessed on 27 March 2020).

29. Padilla, A.; Del Águila, A. Health tourism: Conceptual framework and insights from the case of a Spanish mature destination. Tour. Manag. Stud. 2016, 12, 86-96. [CrossRef]

30. EOI. Turismo de Salud en España; Escuela de Organización Industrial, Ministerio de Industria, Energía y Turismo: Madrid, Spain, 2013.

31. Reddy, G.; York, V.; Brannon, L. Travel for treatment: Students' perspective on medical tourism. Int. J. Tour. Res. 2010, 12, 510-522. [CrossRef]

32. Horowitz, M.; Rosensweig, J. Medical tourism-health care in the global economy. Physician Exec. 2007, 33, 24-30.

33. Bookman, M.; Bookman, K. Medical Tourism in Developing Countries; Palgrave Macmillan: New York, NY USA, 2007.

34. Marlowe, J.; Sullivan, P. Medical tourism: The ultimate outsourcing. Hum. Resour. Plan. 2007, 39, 8-10.

35. Androutsou, L.; Metaxas, T. Measuring the Effeciency of Medical Tourism Industry in EU Members States. J. Tour. Anal. Rev. Análisis Turístico 2015, 26, 115-130. [CrossRef]

36. Ongdee, S. The Future is in Hotel-Spitals; The Nation: New York, NY, USA, 2003; p. 2 B.

37. Cohen, E. Medical travel-A critical assessment. Tour. Recreat. Res. 2010, 35, 225-237. [CrossRef]

38. Hudson, S.; Domestic Medical Tourism: A Neglected Dimension of Medical Tourism Research. Medical Tourism Magazine, 2012; 21. Available online: www.magazine.medicaltourism.com/article/domesticmedical-tourism-a-neglected-dimension-of-medical-tourism-research(accessed on 27 March 2020).

39. Hudson, S.; Li, X. Domestic medical tourism: A neglected dimension of medical tourism research. J. Hosp. Mark. Manag. 2012, 21, 227-246. [CrossRef]

40. DeMicco, F. Medical Tourism and Wellness. Hospitality Bridging Healthcare (H2H); Routledge (Taylor \& Francis Group), Apple Academic Press: Palm Bay, FL, USA, 2017.

41. OECD. Tourism Policy Review of Mexico; OECD Studies on Tourism: Paris, France, 2017.

42. Alberti, F.; Giusti, J.; Papa, F. Competitiveness policies for medical Tourism clusters: Government initiatives in Thailand. Int. J. Econ. Policy Emerg. Econ. 2014, 7, 281-309. [CrossRef] 
43. Beladi, H.; Chao, C.; Ee, M.; Hollas, D. Medical tourism and health worker migration in developing countries. Econ. Model. 2015, 46, 391-396. [CrossRef]

44. Center for Health Tourism Strategy. Why Medical Tourism Clusters Fail. 2019. Available online: https: //medicaltourismstrategy.com/why-medical-tourism-clusters-fail/ (accessed on 27 March 2020).

45. Tobias, A. Evaluation of the lockdowns for the SARS-CoV-2 epidemic in Italy and Spain after one month follow up. Sci. Total Environ. 2020, 725, 138539. [CrossRef]

46. BBC. Coronavirus: UK Quarantine Restrictions Unjust-Spain 2020. PM. 28 July 2020. Available online: https://www.bbc.co.uk/news/uk-53562603 (accessed on 10 August 2020).

47. The Economist. If Covid-19 Devastated Aviation: What if Aviation Doesn't Recover from Covid-19? 20204 July 2020. Available online: https://www.economist.com/the-world-if/2020/07/04/what-if-aviation-doesntrecover-from-covid-19 (accessed on 10 August 2020).

48. Mhalla, M. The impact of novel coronavirus (COVID-19) on the global oil and aviation markets. J. Asian Sci. Res. 2020, 10, 96-104.

49. Suau-Sanchez, P.; Voltes-Dorta, A.; Cugueró-Escofet, N. An early assessment of the impact of COVID-19 on air transport: Just another crisis or the end of aviation as we know it? J. Transp. Geogr. 2020, 86, 102749. [CrossRef] [PubMed]

50. OECD. OECD Economic Outlook; OECD: Paris, France, 2020; Volume 2020, Available online: https://doi.org/ 10.1787/0d1d1e2e-en (accessed on 10 October 2020).

51. Pollard, K. A serious impact on healthcare-related business. International Medical Travel Journal, 22 July 2020. Available online: https:/www.imtj.com/blog/serious-impact-healthcare-related-business/(accessed on 10 October 2020).

52. Myles, P.; Maswime, S. Mitigating the risks of surgery during the COVID-19 pandemic. Lancet 2020, 396, 2-3. [CrossRef]

53. NICE. NICE Publishes New COVID-19 Rapid Guideline on Arranging Planned Care in Hospitals and Diagnostic Services. 2020. Available online: https:/www.nice.org.uk/news/article/nice-publishesnew-covid-19-rapid-guideline-on-arranging-planned-care-in-hospitals-and-diagnostic-services (accessed on 10 October 2020).

54. Royal College of Surgeons of England. Updated Intercollegiate General Surgery Guidance on COVID-19. 2020. Available online: https://www.rcseng.ac.uk/coronavirus/joint-guidance-for-surgeons-v2/ (accessed on 10 October 2020).

55. Lunt, N.; Horsfall, D. Outcomes in Medical Tourism. In Handbook on Medical Tourism and Patient Mobility; Edward Elgar Publishing: Cheltenham, UK, 2015; pp. 461-472.

56. Guy's and St Thomas. Private Patients. 2020. Available online: https://guysandstthomasprivatehealthcare. co.uk/ (accessed on 28 July 2020).

57. Watt, N. Income from Private Patients Soars at NHS Hospital Trusts. The Guardian, 19 August 2014. Available online: https://www.theguardian.com/society/2014/aug/19/private-patient-income-soars-nhsprivatisation(accessed on 10 October 2020).

58. Oliver, D. Private practice by NHS doctors-still controversial? BMJ 2018, 362, k3480. [CrossRef]

59. Neville, S.; Plimmer, G. NHS enlists all English Private Hospitals to Treat Coronavirus. Financial Times, 2020. Available online: https://www.ft.com/content/c9a9be78-6b7b-11ea-89df-41bea055720b(accessed on 10 October 2020).

60. Duncan, P.; Campbell, D. More People Dying at Home during Covid-19 Pandemic-UK Analysis. The Guardian, 8 May 2020. Available online: https://www.theguardian.com/society/2020/may/08/morepeople-dying-at-home-during-covid-19-pandemic-uk-analysis(accessed on 10 October 2020).

61. Woolf, S.; Chapman, D.; Sabo, R.; Weinberger, D.; Hill, L. Excess Deaths From COVID-19 and Other Causes, March-April 2020. JAMA 2020. [CrossRef]

62. Ziemba, E. Re-thinking the patient journey. International Medical Travel Journal, 22 July 2020. Available online: https://www.imtj.com/articles/re-thinking-patient-journey/(accessed on 10 October 2020).

63. Lunt, N.; Horsfall, D.; Smith, R.; Exworthy, M.; Hanefeld, J.; Mannion, R. Market size, market share and market strategy: Three myths of medical tourism. Policy Politics 2014, 4, 597-614. [CrossRef]

64. Barnier, M. Press Release by Michel Barnier Following Round 6 of the Negotiations for a New Partnership between the European Union and the United Kingdom; European Commission: Brussels, Belgium, 2020. 
65. Lunt, N.; Jin, K.; Horsfall, D.; Hanefeld, J. Insights on medical tourism: Markets as networks and the role of strong ties. Korean J. Soc. Sci. 2014, 41, 19-37. [CrossRef]

66. Williams, A.; King, R.; Warnes, T.; Patterson, G. Tourism and international retirement migration: New forms of an old relationship in southern Europe. Tour. Geogr. 2000, 2, 28-49. [CrossRef]

67. Williams, A.; King, R.; Warnes, T. A place in the sun: International retirement migration from northern to southern Europe. Eur. Urban Reg. Stud. 1997, 4, 115-134. [CrossRef] [PubMed]

68. MADECA. Proyecto Turismo y Salud: Nuevos Enfoques y Tendencias 2013; Diputación de Malaga: Malaga, Spain, 2013.

69. Chair of Tourism, Health and Wellbeing. Survey on the Top Ten Medical Treatments in the Province of Malaga; Mimeo, University of Malaga: Málaga, Spain, 2016.

70. Campbell, D. Destination Spain: The Rise and Rise of Fertility Tourism. The Guardian, 22 August 2010. Available online: https://www.theguardian.com/lifeandstyle/2010/aug/22/spain-fertility-tourism(accessed on 10 October 2020).

71. Leon, P. Why Spain is an Increasingly Attractive Destination for Fertility Tourism. EL PAIS, 11 April 2016. Available online: https:/english.elpais.com/elpais/2016/04/11/inenglish/1460369720_769014.html(accessed on 10 October 2020).

72. Trout, M. Spain Becoming a Leading Destination in Fertility Tourism. Tourism Review News, 12 November 2018. Available online: https://www.tourism-review.com/fertility-tourism-developing-fastin-spain-news10817(accessed on 10 October 2020).

Publisher's Note: MDPI stays neutral with regard to jurisdictional claims in published maps and institutional affiliations.

(C) 2020 by the authors. Licensee MDPI, Basel, Switzerland. This article is an open access article distributed under the terms and conditions of the Creative Commons Attribution (CC BY) license (http://creativecommons.org/licenses/by/4.0/). 